\title{
Statistical analysis of heavy metals in Catlacatla, Wallago attu and Tilapia nilotica fish at head Sulemanki in Satlujriver
}

\author{
Qaisar Mehmood ${ }^{1 *}$, Saba Naeem ${ }^{2}$, Saira Sharif ${ }^{1}$ and Nargis Shaheen ${ }^{2}$ \\ 1. Department of Quantitative Methods, University of Management and Technology Lahore-Pakistan \\ 2. Govt. Post Graduate Girls College Bahawalnagar-Pakistan \\ *Corresponding author's email: qaisarm11@gmail.com \\ Citation \\ Qaisar Mehmood, Saba Naeem, Saira Sharif and Nargis Shaheen. Statistical analysis of heavy metals in \\ Catlacatla, Wallago attu and Tilapia nilotica fish at head Sulemanki in Satluj river. Pure and Applied Biology. \\ Vol. 9, Issue 1, pp1216-1222. http://dx.doi.org/10.19045/bspab.2020.90128
}

\begin{tabular}{llll}
\hline \hline Received: 22/11/2019 & Revised: 21/01/2020 & Accepted: 27/01/2020 & Online First: 07/02/2020 \\
\hline \hline
\end{tabular}

\section{Abstract}

The present study was aimed to evaluate the concentration of heavy metals in various organs of three edible fish species (Catlacatla, Wallagoattu and Tilapia nilotica) sampled from contaminated water of River Setluj at head Sulemanki (Okara), Pakistan. The concentration of selected heavy metals iron (Fe), nickel (Ni), Chromium ( $\mathrm{Cr})$, Cadmium $(\mathrm{Cd})$ and lead $(\mathrm{Pb})$ are compared in skin muscles, heart, liver, kidney and gills of same fish and also made comparison among three type of fishes. Overall absorption of heavy metals in three type of fishes is as follow $\mathrm{Fe}>\mathrm{Pb}>\mathrm{Ni}>\mathrm{Cr}>\mathrm{Cd}$. The concentration of heavy metals in all three species of fishes is compared as Tilapia nilotica $>$ Catlacatla $>$ Wallagoattu, while the existence of heavy metals in the organs of fish is also compared, kidney $>$ liver $>$ gills $>$ skin muscles $>$ heart. In analysis of variance accumulation of heavy metals in three species is significantly present, as p-value is less than 0.05 for all heavy metals. Measured elevated levels of metal concentrations in fish organs is pointed out to be risks for potential health of fish, other aquatic organisms and human health.

Keywords: Catlacatla; Heavy metal; organs; Tilapia nilotica and Wallagoattu

\section{Introduction}

With the increase in human population the demand for the food supply has increased. The requirement of fish and shell fish has much increased because they are the excellent supply of protein. Globally men get 25\% protein from fish and shell fish [1]. Fish also has a rich resource of vitamins and minerals which are good for human health [2]. In 2004 nearly $75 \%$ global fish was used for straight human utilization, however in 1997 the demand was 57\% and it will exceed to $98.6 \%$ in 2020 [3]. Metal concentration has both valuable and damaging effects on living organisms. A few of these metals are very injurious in a very little quantity while some biologically important metals are harmful at high concentration. Intake of heavy metals in surplus, reacts with bio element (these elements are necessary for the functioning of life) present in body and destroy the structure of important molecules which take part in many metabolic reactions of body [4]. Heavy metals word is applied to group of metals belonging to metalloids that have atomic gradient greater than $4 \mathrm{~g} / \mathrm{cm}^{3}$ or five times greater than water. These are also 
called trace elements as they are present in very little quantity in natural system [5]. Bioaccumulation of trace elements causes serious health problems and disturbs the environment through food web. Deposition of these elements in body organs particularly in the fish muscles, upset not only the growth and reproduction but also tissues level; caused changes in skin, gills and kidney. Metal deposition in humans causes serious effect on the functioning of liver, kidney, brain and muscle [6].

Aquatic flora and fauna has been polluted, trace element has become the world's major dilemma. These elements are entering the aquatic ecosystem by various sources like use of insecticides, pesticides, fertilizers and leaching [7]. Trace elements are degraded by human body [8]. They are deposited in different organs of the body and make threats to human health. So these trace elements are among the hazardous contaminant that's why they are included in unsafe class of pollutants in river and seas [9]. One of the incidents occurred in the surrounding area of Japanese fishing harbor the Minimata disease which was the result of eating fish and shrimps. They were polluted with methyl mercury and nonorganic mercury, the effluents released by the factories [10].

From the last two decades estimation of heavy metals in fish has been increased in order to provide the safe food to humans and to reduce the injurious effects of these metals. Heavy metals have high molecular weight and poisonous in small amount. These metals may build up in living creature when they are taken in and then deposited quickly in body. They cannot metabolize easily. They enter into the water by industrial waste and user's material. Acid rain also plays a role in breaking down the soil and leach trace metals into the water (streams, rivers, lakes and ground water. Trace elements bioaccumulation may occur in the fishes and other animals. Bioaccumulation means deposition of poisonous elements in the body organs with passage of time. Generally heavy metals are divided into two classes vital and non-vital. The non-vital elements includes: $\mathrm{Al}, \mathrm{Hg}$, $\mathrm{Cd}, \mathrm{Sn}$ and $\mathrm{Pb}$ and have no biochemical activity and their toxic effect increases with the increase in concentration. Vital elements includes: $\mathrm{Cu}, \mathrm{Zn}, \mathrm{Cr}, \mathrm{Ni}, \mathrm{Co}$, Mo and $\mathrm{Fe}$. Food is the main path for taking these heavy metal ions. Fish is also the element of this diet; it is not shocking that some of the heavy metals pass to human beings through contaminated fish [11]. The purpose of the present study is to illustrate the comparison of heavy metals, Fe (Iron), $\mathrm{Ni}$ (Nickel), $\mathrm{Cr}$ (Chromium), $\mathrm{Cd}$ (Cadmium) and $\mathrm{Pb}$ (Lead) concentration in the different organs of Catlacatla, Wallagoattu and Tilapia nilotica fish.

In recent years, there is an increasing tendency to check effects of dense metals on aquatic biota especially the fishes because it is a staple diet of humans in some countries, being a part of food chain, it should be free of pollutants. Marine water is often checked for heavy metal contamination in rivers and streams, and its ground surface and organisms. Investigation of heavy metals in body cells is the big source for establishing public health standard. The Arabian Gulf was the center of attraction for research in recent past years because of accidental oil spill in 1991. So the heavy metals storage was checked in marine fish Epinephelus micro don. They also act as pollution indicator for marine life and other organisms [12]. Examination of dense metals on River Ravi made by the researchers by observing the heavy metal contents in gills, liver, kidneys, fins, scale, skin and bones of fishes Labeorohita, Catlacatla and Cirrhiniamrigala. Quantity of heavy metals was varying because it was based on the season for collection of the samples. Deposition of heavy metals was high in vital organs and less in muscle and fat. River Ravi has lot of heavy metals as reported by the EPA. Through wet digestion process dense metals concentration was determined by absorption spectrometry. Heavy metal have 
tenacity in surface water, found in colloidal and particulate form in rivers, and is considered as prominent way for the transportation of metals [13]. Anthropogenic activities have serious effect on aquatic life. Normally metals are required for healthy life activities in low quantity. But the heavy metals have lethal effects for aquatic biota especially for the fishes. In fishes the entrance of these metals is through body surface, gills and the digestive tract. Food may be the one factor by which metal deposition occurs in the body. One of the major threats to fish life is the industrial effluents and domestic sewage, released in to the freshwater bodies. Heavy metal deposition is checked on fishes of River Ravi and its related tributaries. Fishes were collected from Baloki head works and Sindhnai barrage. Heavy metal concentration was analyzed by SMEWW method, after doing wet digestion, sample analysis is done though Atomic absorption spectrophotometer. Standing water is quite different from the flowing water. Its depth, flowing rate, geology and turbidity are totally different; contaminants enter the river, flow downstream but their concentration cannot be changed. Huge amount of industrial waste and sewage water are released into the river through tributaries which changes quality of river bed sediments [14]. When stress condition (manganese) were applied to fishes, show great weight loss. Stress has a profound effect on metabolism of fishes and so reduction in growth was observed in freshwater fishes [15]. Heavy metals absorbed in the body of fish through three ways: gills, body surface and digestive track. Level of heavy metals was checked in different organs of freshwater fish that have direct contact with polluted water. It was found that absorption cadmium and lead is high in tissues than other heavy metals, this level is raised because fish is first consumed in aquatic biota. The chromium absorption in rivers and lakes is about one to ten micro gram per liter while the EPA has set the level up to 50 to 100 microgram per liter for human safety and aquatic life. Chromium has a lethal effect on kinds of fish's effect on blood result in anemia, eosiophilia, lymphocytosis and bronchial and renal wounds [16]. Different heavy metals concentration is determined in the organs of fish Tilapia (Oreochromisniloticus). Heavy metals are the major contaminants that enter our body through food. Some metals bound to body tissues such as cadmium bind to kidneys and lead to bones. The measurement is done through inductively-coupled plasma mass spectrometry. By this method zinc absorption was estimated. Study showed that concentration of heavy metal is high in liver, than gills and muscles. It was noted that metabolite region of body like liver, gills and kidney are suspected to have high metal absorption than muscles [17]. To estimate the outcome of heavy metals (Fe, $\mathrm{Cu}, \mathrm{Cr}$ and $\mathrm{Pb}$ ) on the tissue organs of fish species Cyprinuscarpioand, Wallago attu their samples were collected from Indus river their deposition in gills, kidney, liver and muscles is matched up to International standard of food fish. There is noteworthy dissimilarity in the deposition of heavy metals in the visceral organs of the two fishes. Each metal is with tolerable level as mentioned by International authorities like World health organization, FAO and FEPA [18].

\section{Materials and methods}

The study was carried out the fishing of Sutlej River at head Sulemaniki District Okara, which is located in the south-east of the Punjab, Pakistan. The residents of District Oakara and District Bahawalnagar are dependent on the Sutlej River for fishing and fish consumption. In this area, an important issue is to check the quality of fish meat with regards to heavy metals in organs of fish. Sutlej river inter in Pakistan at District Qasor from India with heavy metals discharge due to industrialization and urbanization greatly affect the aquatic life. Fish is an important member of aquatic food chain and is sensitive to heavy metal. Fish is not only the pollution indicator of 
aquatic ecosystem but also the main sources of proteins in human nutrition. For the examination of heavy metals three species Catlacatla, Wallagoattu and Tilapia nilotica of adult fishes were taken at head sulemaniki.

After identification, fishes were washed with deionized water, sealed in polythene bags and kept in freezer at $-20^{\circ} \mathrm{C}$ until used for chemical analysis. Then three samples of each tissue (liver, gills, muscles, kidney and heart) from each species of fish were dissected. The representative samples were cautiously sealed in tagged sampled bottles containing aqueous Bouin's fixative for 24 hours, and sent to the laboratory at Mycology department of Botany, University of Punjab, Lahore for the examination of heavy metals for $\mathrm{Fe}, \mathrm{Ni}, \mathrm{Cr}$, $\mathrm{Cd}$, and $\mathrm{Pb}$.

One gram of each wet fish tissues (liver, gills and kidney, heart and skin muscles) was digested with $2 \mathrm{ml}$ of $\mathrm{HNO}_{3}$ and $1 \mathrm{ml}$ of $\mathrm{H}^{2} \mathrm{SO}_{4}$ in a volume metric flask, digestion was carried out on a hot plate $\left(200^{\circ} \mathrm{C}\right.$ to $250^{\circ} \mathrm{C}$ ) until transparent or vine green color was obtained. The digested solution was diluted up to $100 \mathrm{ml}$ and from this $50 \mathrm{ml}$ of each sample is taken. Each sample was filtered through 0.42-micro meter filter paper; finally each sample was transferred to polythene bottle and sealed to avoid contamination and evaporation. All digested samples are stored at $4^{0} \mathrm{C}$ before heavy metal analysis [19].

All reagents were of analytical grade. Double deionized water was used for all digestion. $\mathrm{HNO}_{3}$ and $\mathrm{H}_{2} \mathrm{SO}_{4}$ were of suprapure quality (Merck, Germany). All glassware were cleaned by soaking in dilute $\mathrm{HNO}_{3}(10 \%)$ and rinsed with deionized water before to use. For each element, standard solution used for calibration (sigma) is prepared by diluting the stock solutions to the concentration of 1000 $\mathrm{mg} / \mathrm{L}$. Standard reference materials are used [19].

For the observed data mean values, standard error and analysis of variance were calculated for heavy metals $(\mathrm{Fe}, \mathrm{Ni}, \mathrm{Cr}, \mathrm{Cd}$ and $\mathrm{Pb}$ ) and tissues (kidney, liver, skin muscles, heart and gills) of each fish species. Data were analyzed by using Statistical package SPSS 21 at level of significance was $\mathrm{P}<0.05$.

\section{Results and discussion}

In table 1 water sample at head sulemanki has $0.1410 \pm 0.01674 \mathrm{mg} / \mathrm{l}$ of fe, while the amount of iron in Catlacatla, Wallago attu and Tilapia nilotica fish is $1.8751 \pm 0.28851$, $1.5285 \pm 0.06232$ and $2.4517 \pm 0.53667$ which shows Tilapia nilotica has more amount of fe than other two species of fishes. Amount of Ni in Tilapia nilotica fish is more than other two type of fishes and in water sample $\mathrm{Ni}$ is $0.0273 \pm 0.00203 \mathrm{mg} / \mathrm{l}$. While amount of $\mathrm{Cr}, \mathrm{Cd}$ and $\mathrm{Pb}$ in these types of fishes is compared as Wallagoattu $>$ Catlacatla $>$ Tilapia nilotica, Wallago attu $>$ Tilapia nilotica $>$ Catlacatla and Tilapia nilotica $>$ Catlacatla $>$ Wallago attu.

Critical analysis of Iron (Fe): in table 2, 3 and 4, concentration of iron in the organs of Catlacatla fish is ranges from $3.9090 \pm$ 0.14271 to $0.7113 \pm 0.00606$, in Wallago attu ranges from $1.7557 \pm 0.00644$ to $1.1127 \pm 0.00467$ and Tilapia niloticafishis from $6.1277 \pm 0.00970$ to $0.0320 \pm 0.00351$ $\mathrm{mg} / \mathrm{l}$. Comparing the amount of iron in different organs of these fish species we found thatin skin musclesCatlacatla > Tilapia nilotica $>$ Wallago attu, in heart Wallago attu $>$ Catlacatla $>$ Tilapia nilotica, in liver Catlacatla $>$ Tilapia nilotica $>$ Wallago attu, in kidneyTilapia nilotica $>$ Wallago attu $>$ Catlacatla and in gills Tilapia nilotica $>$ Wallago attu $>$ Catlacatla. The value of F- statistics (967.804) in ANOVA table 5 for iron is significant as p-value is less than 0.05 , which shows that a considerable amount of heavy metal iron is detected in all samples of each type of fish.

Comparing Nickel (Ni): in table 2, 3 and 4, existence of heavy metal nickel in the organs of Catlacatla fish is ranges from $0.4553 \pm 0.00384$ to $0.0867 \pm 0.00882$, in Wallago attu ranges from $0.3443 \pm 0.01501$ to $0.1440 \pm 0.01179$ and in Tilapia nilotica 
fish is from $0.3550 \pm 0.00379$ to $0.1877 \pm$ $0.00825 \mathrm{mg} / \mathrm{l}$. Comparing the amount of nickel in different organs of three fish species we found that in skin muscles Tilapia nilotica $>$ Catlacatla $>$ Wallago attu, in heart Wallago attu $>$ Catlacatla $>$ Tilapia nilotica, in liver Catlacatla $>$ Wallago attu > Tilapia nilotica, in kidneyTilapianilotica $>$ Catlacatla $>$ Wallago attu and in gills Tilapia nilotica $>$ Wallago attu $>$ Catlacatla. In ANOVA table 5 the value of F-test for nickel is 99.52 and its p-value is 0.0000 , which shows that nickel occur significantly in all samples of each type of fish.

Comparing Chromium (Cr): in table 2, 3 and 4, presence of the amount of heavy metal Chromium in the organs of Catlacatla fish is ranges from $0.06075 \pm 0.00067$ to $0.02003 \pm 0.00404$, in Wallago attu ranges from $0.0803 \pm 0.00067$ to $0.0277 \pm 0.00088$ and in Tilapia nilotica fishis from $0.0413 \pm 0.00067$ to $0.0137 \pm$ $0.00203 \mathrm{mg} / \mathrm{l}$. While comparing the amount of Chromium in different organs of these fish species we explore that in skin musclesTilapia nilotica $>$ Wallago attu $>$ Catlacatla, in heart Wallago attu > Catlacatla $>$ Tilapia nilotica, in liver Wallago attu > Tilapia nilotica > Catlacatla, in kidney Catlacatla $>$ Wallago attu $>$ Tilapia nilotica and in gills Tilapia nilotica $>$ Wallago attu $>$ Catlacatla. In ANOVA table 5 the value of F-test for Chromium is 102.097 and its p-value is less than 0.05 , which shows that a significant amount of Chromium is detected in all samples of each type of fish.

Discussing the metal Cadmium $(\mathrm{Cd})$ : from table 2, 3 and 4, the Heavy metal Cadmium in the organs of Catlacatla fish is ranges from $0.1020 \pm 0.00577$ to $0.0000 \pm 0.0000$, in Wallago attu ranges from $0.2517 \pm 0.01785$ to $0.0223 \pm 0.00186$ and in Tilapia nilotica fish is from $0.1360 \pm 0.00971$ to $0.0487 \pm$ $0.00260 \mathrm{mg} / \mathrm{l}$. Comparing the amount of Cadmium in different organs of these fish species we found that in skin musclesWallagoattu $>$ Catlacatla $>$ Tilapia nilotica, in heart Tilapia nilotica $>$ Wallago attu $>$ Catlacatla, in liver Wallago attu $>$ Catlacatla $>$ Tilapia nilotica, in kidneyCatlacatla $>$ Wallago attu $>$ Tilapia nilotica and in gills Tilapia nilotica $>$ Catlacatla $>$ Wallago attu. The value of Ftest for Cadmium is 58.77 and its p-value is less than 0.05, which shows that a significant amount of Cadmium is found in all samples of each type of fish.

Comparing Lead $(\mathrm{Pb})$ : in table 2, 3 and 4, the presence of the amount of heavy metal Lead in the organs of Catlacatla fish is ranges from $1.0043 \pm 0.07738$ to $0.1477 \pm 0.01333$, in Wallago attu ranges from $0.6617 \pm 0.7448$ to $0.3750 \pm 0.03743$ and in Tilapia nilotica fish is from $1.0367 \pm$ 0.06282 to $0.3297 \pm 0.02973 \mathrm{mg} / \mathrm{l}$. Comparing the amount of Lead in different organs of these fish species we found that in skin muscles Catlacatla $>$ Wallago attu $>$ Tilapia nilotica, in heart Tilapia nilotica $>$ Wallago attu $>$ Catlacatla in liver Catlacatla $>$ Wallago attu $>$ Tilapia nilotica , in kidney Tilapianilotica > Catlacatla $>$ Wallago attu and in gills Catlacatla $>$ Wallago attu $>$ Tilapia nilotica. In ANOVA table 5 the value of Ftest for Lead is 29.747 and its p-value is less than 0.05 , which shows that a significant amount of Lead is present in all samples of fishes.

Table 1. Descriptive statistics of heavy metals in three fish species

\begin{tabular}{|c|c|c|c|c|c|}
\hline Metals & $\mathbf{N}$ & $\begin{array}{c}\text { Catlacatla } \\
\left(\overline{\boldsymbol{X}} \pm \boldsymbol{s}_{\overline{\boldsymbol{x}}}\right)\end{array}$ & $\begin{array}{c}\text { Wallago attu } \\
\left(\overline{\boldsymbol{X}} \pm \boldsymbol{s}_{\overline{\mathbf{x}}}\right)\end{array}$ & $\begin{array}{c}\text { Tilapia nilotica } \\
\left(\overline{\boldsymbol{X}} \pm \boldsymbol{s}_{\overline{\boldsymbol{x}}}\right)\end{array}$ & $\begin{array}{c}\text { Water } \\
\left(\overline{\boldsymbol{X}} \pm \boldsymbol{s}_{\overline{\bar{x}}}\right)\end{array}$ \\
\hline $\mathrm{Fe}$ & 15 & $1.8751 \pm 0.28851$ & $1.5285 \pm 0.06232$ & $2.4517 \pm 0.53667$ & $0.1410 \pm 0.01674$ \\
$\mathrm{Ni}$ & 15 & $0.2531 \pm 0.3244$ & $0.2235 \pm 0.02035$ & $0.2663 \pm 0.01552$ & $0.0273 \pm 0.00203$ \\
$\mathrm{Cr}$ & 15 & $0.0351 \pm 0.00391$ & $0.0441 \pm 0.00548$ & $0.0273 \pm 0.00260$ & $0.0113 \pm 0.00067$ \\
$\mathrm{Cd}$ & 15 & $0.0600 \pm 0.00926$ & $0.0947 \pm 0.02223$ & $0.0778 \pm 0.00847$ & $0.0617 \pm 0.00581$ \\
$\mathrm{~Pb}$ & 15 & $0.5435 \pm 0.07696$ & $0.5070 \pm 0.03813$ & $0.5663 \pm 0.07015$ & $0.0983 \pm 0.00498$ \\
\hline
\end{tabular}


Table 2. Descriptive statistics of heavy metals in organs of Catlacatla fish

\begin{tabular}{|c|c|c|c|c|c|c|}
\hline Organs & $\mathbf{N}$ & $\mathbf{F e}\left(\overline{\boldsymbol{X}} \pm \boldsymbol{s}_{\overline{\boldsymbol{x}}}\right)$ & $\mathbf{N i}\left(\overline{\boldsymbol{X}} \pm \boldsymbol{s}_{\overline{\boldsymbol{x}}}\right)$ & $\mathbf{C r}\left(\overline{\boldsymbol{X}} \pm \boldsymbol{s}_{\overline{\boldsymbol{x}}}\right)$ & $\mathbf{C d}\left(\overline{\boldsymbol{X}} \pm \boldsymbol{s}_{\overline{\boldsymbol{x}}}\right)$ & $\mathbf{P b}\left(\overline{\boldsymbol{X}} \pm \boldsymbol{s}_{\overline{\boldsymbol{x}}}\right)$ \\
\hline Skin Muscle & 3 & $1.7307 \pm .02074$ & $.2107 \pm .00593$ & $.0310 \pm .00153$ & $.0520 \pm .00764$ & $.6033 \pm .00333$ \\
Heart & 3 & $.7113 \pm .00606$ & $.2260 \pm .01950$ & $.0390 \pm .00153$ & $.0000 \pm .00000$ & $.1477 \pm .01333$ \\
Liver & 3 & $3.9090 \pm .14271$ & $.4553 \pm .00384$ & $.0247 \pm .00145$ & $.0717 \pm .00426$ & $.5760 \pm .02219$ \\
Kidney & 3 & $1.5033 \pm .01534$ & $.2867 \pm .01384$ & $.0607 \pm .00067$ & $.1020 \pm .00577$ & $.3860 \pm .03724$ \\
Gills & 3 & $1.5210 \pm .06655$ & $.0867 \pm .00882$ & $.0200 \pm .00404$ & $.0743 \pm .00285$ & $1.0043 \pm .07738$ \\
\hline
\end{tabular}

Table 3. Descriptive statistics of heavy metals in organs of Wallago attu fish

\begin{tabular}{|l|c|l|l|l|l|l|}
\hline Organs & $\mathrm{N}$ & $\mathrm{Fe}\left(\bar{X} \pm s_{\bar{x}}\right)$ & $\mathrm{Ni}\left(\bar{X} \pm s_{\bar{x}}\right)$ & $\mathrm{Cr}\left(\bar{X} \pm s_{\bar{\chi}}\right)$ & $\mathrm{Cd}\left(\bar{X} \pm s_{\bar{x}}\right)$ & $\mathrm{Pb}\left(\bar{X} \pm s_{\bar{x}}\right)$ \\
\hline Skin & 3 & $1.1127 \pm .00467$ & $.1477 \pm .00825$ & $.0317 \pm .00120$ & $.0940 \pm .01137$ & $.3667 \pm .02801$ \\
Muscle & 3 & $1.6520 \pm .01185$ & $.3443 \pm .01501$ & $.0527 \pm .00318$ & $.0423 \pm .00186$ & $.6617 \pm .07448$ \\
Heart & 3 & $1.4507 \pm .04864$ & $.2640 \pm .00603$ & $.0803 \pm .00067$ & $.2517 \pm .01785$ & $0.5073 \pm .07389$ \\
Liver & 3 & $1.7557 \pm .00644$ & $.2173 \pm .00913$ & $.0277 \pm .00088$ & $.0630 \pm .00551$ & $0.3750 \pm .03743$ \\
Kidney & 3 & $1.6713 \pm .01543$ & $.1440 \pm .01179$ & $.0280 \pm .00173$ & $.0223 \pm .00186$ & $.6243 \pm .01697$ \\
Gills & & & & & & \\
\hline
\end{tabular}

Table 4. Descriptive statistics of heavy metals in organs of Tilapia nilotica fish

\begin{tabular}{|c|c|c|c|c|c|c|}
\hline Organs & $\mathbf{N}$ & $\mathbf{F e}\left(\overline{\boldsymbol{X}} \pm \boldsymbol{s}_{\overline{\boldsymbol{x}}}\right)$ & $\mathbf{N i}\left(\overline{\boldsymbol{X}} \pm \boldsymbol{s}_{\overline{\boldsymbol{x}}}\right)$ & $\mathbf{C r}\left(\overline{\boldsymbol{X}} \pm \boldsymbol{s}_{\overline{\boldsymbol{x}}}\right)$ & $\mathbf{C d}\left(\overline{\boldsymbol{X}} \pm \boldsymbol{s}_{\overline{\boldsymbol{x}}}\right)$ & $\mathbf{P b}\left(\overline{\boldsymbol{X}} \pm \boldsymbol{s}_{\overline{\boldsymbol{x}}}\right)$ \\
\hline Skin Muscle & 3 & $1.6210 \pm .04080$ & $.2337 \pm .01889$ & $.0413 \pm .00067$ & $.0487 \pm .00260$ & $.3297 \pm .02973$ \\
Heart & 3 & $.0320 \pm .00351$ & $.1877 \pm .00825$ & $.0213 \pm .00067$ & $.0730 \pm .00462$ & $1.0367 \pm .06282$ \\
Liver & 3 & $2.2537 \pm .06443$ & $.2630 \pm .00874$ & $.0270 \pm .00153$ & $.0697 \pm .00984$ & $.3687 \pm .01408$ \\
Kidney & 3 & $6.1277 \pm .00970$ & $.2923 \pm .00393$ & $.0137 \pm .00203$ & $.0617 \pm .00088$ & $.5370 \pm .06612$ \\
Gills & 3 & $2.2243 \pm .01202$ & $.3550 \pm .00379$ & $.0330 \pm .00173$ & $.1360 \pm .00971$ & $.5593 \pm .06502$ \\
\hline
\end{tabular}

Table 5. ANOVA Table for the heavy metals in the organs of fishes

\begin{tabular}{|c|c|c|c|c|c|c|}
\hline & & $\begin{array}{c}\text { Sum of } \\
\text { Squares }\end{array}$ & Df & $\begin{array}{c}\text { Mean } \\
\text { Square }\end{array}$ & $\mathbf{F}$ & Sig. \\
\hline \multirow{3}{*}{$\mathrm{Fe}$} & Between Groups & 94.319 & 15 & 6.288 & 967.804 & .000 \\
\hline & Within Groups & .208 & 32 & .006 & & \\
\hline & Total & 94.526 & 47 & & & \\
\hline \multirow{3}{*}{$\mathrm{Ni}$} & Between Groups & .500 & 15 & .033 & 99.525 & .000 \\
\hline & Within Groups & .011 & 32 & .000 & & \\
\hline & Total & .511 & 47 & & & \\
\hline \multirow{3}{*}{$\mathrm{Cr}$} & Between Groups & .014 & 15 & .001 & 102.097 & .000 \\
\hline & Within Groups & .000 & 32 & .000 & & \\
\hline & Total & .015 & 47 & & & \\
\hline \multirow{3}{*}{$\mathrm{Cd}$} & Between Groups & .142 & 15 & .009 & 58.770 & .000 \\
\hline & Within Groups & .005 & 32 & .000 & & \\
\hline & Total & .147 & 47 & & & \\
\hline \multirow{3}{*}{$\mathrm{Pb}$} & Between Groups & 2.944 & 15 & .196 & 29.747 & .000 \\
\hline & Within Groups & .211 & 32 & .007 & & \\
\hline & Total & 3.155 & 47 & & & \\
\hline
\end{tabular}

\section{Conclusion}

Absorption of heavy metals in three fish species are $\mathrm{Fe}>\mathrm{Pb}>\mathrm{Ni}>\mathrm{Cr}>\mathrm{Cd}$. The concentration of heavy metals in all three species of fishes is compared as Tilapia nilotica $>$ Catlacatla $>$ Wallagoattu, while the existence of heavy metals in the organs of fishes is also compared, kidney $>$ liver $>$ gills $>$ skin muscles $>$ heart. Accumulation of all heavy metals is significantly present in the samples of the species of fish.

\section{Authors' contributions}

Conceived and designed the experiments: $\mathrm{S}$

Naeem, Performed the experiments: S Naeem \& N Shaheen, Analyzed the data: Q Mehmood, Contributed reagents/materials/analysis tools: Q Mehmood \& S Sharif, Wrote the paper: Q Mehmood \& S Naeem.

\section{References}

1. Bahnasawy M, Khidr AA \& Dheina N (2009). Seasonal variations of heavy 
metals concentrations in mullet, Mugilcephalus and Liza ramada (Mugilidae) from Lake Manzala. Egypt. $J$ of ApplSci Res 5(7): 845-852.

2. AlBader N (2008). Heavy Metal Levels in Most Common Available Fish Species in Saudi Market. J of Food Technol 6(4): 173-177.

3. Retnam A \&Zakaria MP (2010). Hydrocarbons And Heavy Metals Pollutants In Aquaculture,http://psasir.upm.edu.my/id /eprint/5601/1/5.pdf.

4. U F \& G TW (1981). Metal pollution in the aquatic environment. Berlin, Heidelberg, Germany: Springer-Verlag 272: 486.

5. Duruibe OJ, Ogwuegbu MC \&Egwurugwu JN (2007). Heavy metal pollution and human biotoxic effects. Inter J of Phy Sci 2: 112-118.

6. Fabio PA, Savassi LA, Santos HB, Gomes MVT \& Bazzoli N (2015). Bioaccumulation of mercury, cadmium, znic, chromium. Annals of the Brazilian Academy of Science.

7. Fevzi Y (2009). The comparison of heavy metal concentrations $(\mathrm{Cd}, \mathrm{Cu}, \mathrm{Mn}$, $\mathrm{Pb}$, and $\mathrm{Zn}$ ) in tissues of three Economically important fish (Anguilla anguilla, Mugilcephalus, Oreochromis niloticus) Inhabiting Koycegiz LakeMiugla (Turkey). Turk J of Sci \& Technol 4(1): 7-15.

8. Castro MG \& Méndez MA (2008). Heavy metals: Implications associated to fish consumption. Environ Toxicol and Pharmacol 26: 263-271.

9. Heba H, Abu IZ, Osama A, Abuzinadah, Faragalla A \& AlHasawi Z (2015). Determination of Some Heavy Metals in Tissues andOrgans of Three Commercial Fish Species at Al-Hudaydah, Red Sea Coast of Western Yemen. World $J$ of Fish and Marine Sci 7(3): 198-208.

10. DuralM, Göksu MZL \& Ozak AA (2007). Investigation of heavy metal levels in economically important fish species captured from the Tuzla lagoon. Food Chem 102(1): 415-421.
11. Zeitoun M (2014). Impact of Water Pollution with Heavy Metals on Fish Health: Overview and Updates. Global Vet 12(2): 219-231.

12. Fevzi Y, Özdemir N, Demirak A \& Tuna AL (2007). Heavy metal levels in two fish species Leuciscuscephalus and Lepomisgibbosus. Food Chem 100(2): 830-835.

13. Jabeen A, Huang X \& Amir M (2015). The challenges of water pollution, threat to public health flaws of water laws and policies in Pakistan. $J$ of Water Resos and Protectione 1516-1526.

14. Javed M (2005). Heavy metal contamination of freshwater Fish and bed sediments in the River Ravi Stretch and related tributaries. Pak $J$ of Bioolgical Sci 8(10): 1337-1341.

15. Hayat S, Javed M \& Razzaq S (2007). Growth performance of metal stressed major carps vizCatlacatla, Labeorohita and Cirrhinamrigala reared under semiintensive culture system. Pak Vet J 27: 812 .

16. Rauf A, Javed M\& Abdullah M (2009). Heavy metal levels in three major carps (Catlacatla, Labeorohita and Cirrhinamrigala) from the River Ravi, Pakistan. Pak Vet J 29: 24-26.

17. Taweel AKA, Othman MS \& Ahmad AK (2012). Analysis of heavy metal concentrations in Tilapia Fish (Oreochromis niloticus) from four selected markets in Selangor, Peinnsular Malaysia. J BiolSci 12(3): 138-145.

18. Mahboob S, Kausar S, Jabeen F, Sultana S, Sultana T \& AlGhanim KA (2016). Effect of heavy metals on liver, kidney, gills and muscles of Cyprinuscarpio and Wallago attuinhabted in the Indus. Braz. Arch Biol Technol 59: e16150275.

19. Qadir AM \&Riffat N (2011). Heavy metals in eight edible fish species from two polluted Tributaries (Aik and Palkhu) of the River Chenab, Pakistan. Biol Trace Elements Resos 143: 15241540. 